DOI: $10.20472 / B M .2021 .9 .1 .001$

\title{
INSTITUTIONAL SUSTAINABILITY OF ST. PAUL UNIVERSITY PHILIPPINES USING THE FOUR PERSPECTIVES OF THE BALANCED SCORECARD
}

\author{
SHIRLEY ENRIQUEZ
}

\begin{abstract}
:
The study aimed to assess the institutional sustainability of St. Paul University Philippines (SPUP) using the four perspectives of the balanced scorecard, namely: internal processes; learning and innovation, customer and financial perspectives. Furthermore, it considered the strengths, weaknesses, opportunities and threats of SPUP in the balanced scorecard inorder to come up with proposed strategies. This study employed the quantitative descriptive method to assess the University's performance along the four perspectives of the balanced scorecard. The primary data were obtained using a survey questionnaire. The secondary data includes the financial statements, enrollment summary, faculty profile, faculty performance evaluation, number of employees, and number of resigned full-time faculty for academic year, 2015-2016 to 2017-2018. One hundred ninety-three (193) participants were obtained through stratified sampling to include office staff and maintenance personnel, faculty, lay administrators, students and parents. Data were treated using frequency counts, mean, and ratios. Results show that the scorecard of SPUP has positive performance in the internal processes, learning and growth, and customers' perspectives. It adopted aggressive working capital management in its financial perspective of the balanced scorecard brought by low liquidity and short-term solvency. It has less performance in the financial perspective of the Balanced Scorecard.
\end{abstract}

\section{Keywords:}

Keywords: institutional sustainability, balanced scorecard, internal processes, learning and innovation, customer, financial perspective

JEL Classification: D21, D22, 121

\section{Authors:}

SHIRLEY ENRIQUEZ, St. Paul University Philippines, Philippines, Email: senriquez@spup.edu.ph

\section{Citation:}

SHIRLEY ENRIQUEZ (2021). Institutional Sustainability of St. Paul University Philippines Using the Four Perspectives of the Balanced Scorecard. International Journal of Business and Management, Vol. IX(1), pp. 1-33., 10.20472/BM.2021.9.1.001 


\section{Introduction}

Institutional sustainability assessment (ISA) in higher education refers to universities assessing their sustainability performance across operational and educational activities. (Kosta, K.2019). This was used by most universities to evaluate their sustainability performance and measure progress. It is perceived as a necessary step for sustainability implementation as it makes progress operational and facilitates decision-making. (Alghamdi et al. 2017).

The Balanced Scorecard introduced by Robert S. Kaplan and David P. Norton (1992) is a measure that drives performance. It provides executives with a comprehensive framework that translates a company's strategic objectives into a coherent set of performance measures. The scorecard provides an enterprise view of an organization's overall performance by integrating financial measures with other key performance indicators around customer perspectives, internal business processes, and organizational growth, learning, and innovation.

Karathanos and Karathanos (2005) described how the Baldrige Education Criteria for Performance Excellence has adapted the concept of BSC to education and discuss significant difference as well as similarities between BSC for Business and BSC for education.

Financial perspective simply measures the revenue growth, investment return and cost reduction by gathering financial data and reviewing business performance on financial performance. Kalendar,Zeynep et (2016) stated that business management and measurement needed to change because the world changed and the structure of business management has evolved through time. The financial perspective can measure the effectiveness of all the other perspectives. Johansson and Larson (2015) stated that this perspective indicates whether the previous strategies have been used to lead to economic success and seeks to define the financial performance of strategies meant to achieve revenue growth and cost reduction.

Internal processes perspective generally identifies more effective processes for the organization to achieve high efficiency in terms of its objectives. In this study, internal process include the basic processes, technology and innovation effectiveness, employee process issues and research.

Learning and growth perspective of employee skills, training, and administration of routine process. It focuses on internal skills and capabilities, in order to align them to the strategic goals of the organization. Kosta, Katerina (2019). In this study, learning and growth perspective covers training, opportunity to be empowered, communications within the University, reward policy to encourage performance, benchmarking for new ideas, mentorship and best practices of the University.

Customer perspective consists of measures relating to the most desired customer groups. This perspective focuses on market share, customer satisfaction, loyalty and acquisition. Customer values and profitability can be considered as key measures that enable an organization to create a clear vision of the customers whom it should target in terms of their needs and expectations from the company. Kosta, Katerina (2019). This study considered the extent by which the customers were satisfied with the various activities/programs/facilities/services of the St. Paul University Philippines. 
St. Paul University Philippines has been endeavoring for excellence for the past one hundred seven (107) years of existence as an educational institution. It has always been proving its commitment and dedication to quality education and excellence.

The objective of this study is to assess the institutional sustainability of St. Paul University Philippines using the four perspectives of the balanced scorecard considering the four (4) schools in the tertiary level of the University namely: School of Arts, Sciences and Teacher Education (SASTE), School of Business, Accountancy and Hospitality Management (SBAHM), School of Information Technology and Engineering (SITE), School of Nursing and Allied Health Sciences (SNAHS). The Christian Formation (CF) takes care of the Theology subjects for all the four schools, thus, it is also considered in this study.

INPUT

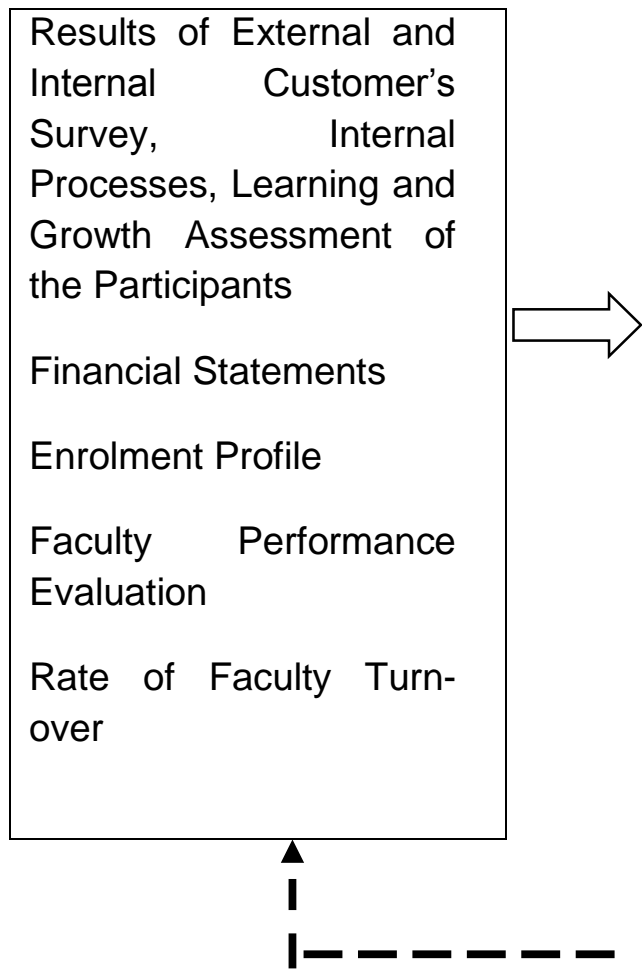

PROCESS

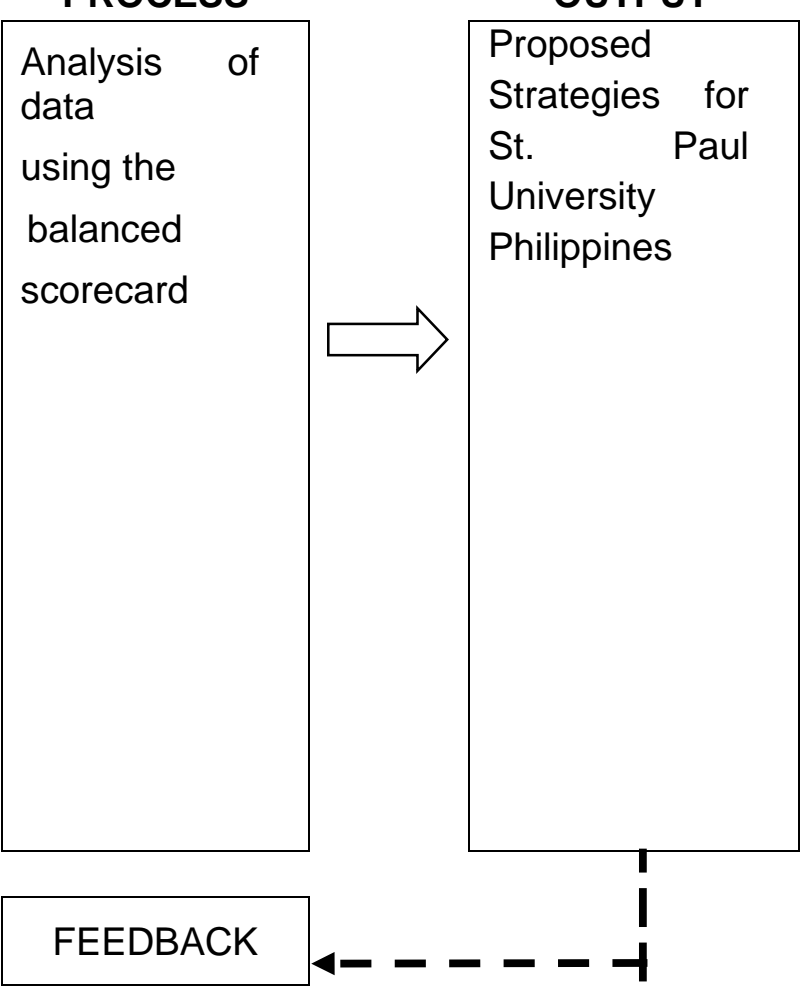

Figure 1.1 Paradigm of the Study

As reflected in the paradigm, for the attainment of the objectives of the study, it considered the following input: results of external and internal customer's survey, internal processes, learning and growth assessment of the participants, financial statements; enrolment profile; faculty performance evaluation and rate of faculty turnover.

The inputs were subjected to analysis in order to come up with a proposed strategies for St. Paul University Philippines towards institutional sustainability. 


\section{Statement of the Problem}

This study aimed to evaluate the institutional sustainability of St. Paul University Philippines (SPUP) using the four perspectives of the balanced scorecard. Specifically, it sought to provide answers to the following questions:

1. What is the profile of St. Paul University Philippines as to: Years of operation, Number of employees and Enrolment?

2. What is the performance of St. Paul University Philippines based on the following balanced scorecards perspectives?

2.1 internal processes;

2.2 customer perspective;

2.3 learning and growth perspective; and

2.4 financial perspective

3. What are the strengths, weaknesses, opportunities and threats of SPUP in the balanced scorecard?

4. What strategies can be proposed for the institutional sustainability of SPUP?

\section{METHODOLOGY}

\section{Research Design}

The study used the descriptive research design. Descriptive method was employed to determine the participant's assessment on the sustainability of SPUP using the four perspectives of the balanced scorecard.

\section{Participants of the Study}

The participants of this study were one hundred ninety-three (193) which consists of the office staff, maintenance personnel, faculty from the different schools in SPUP namely: School of Arts, Sciences and Teacher Education (SASTE), School of Business, Accountancy and Hospitality Management (SBAHM), School of Information, Technology and Engineering (SITE), School of Nursing and Allied Health Sciences (SNAHS), Christian Formation (CF), lay administrators, students and parents obtained through stratified sampling

\section{Instrumentation}

The primary data were obtained using a survey questionnaire. The secondary data includes the financial statements, enrollment summary, faculty profile, faculty performance evaluation, number of employees, results of the study on community services, results of the study on external 
productivity of the graduates, scholarship for students, board exam results and number of resigned full-time faculty for academic year, 2015-2016 to 2017-2018.

\section{Data Gathering Procedures}

The researcher, upon the approval by the University President to the conduct the study, framed letters of request to the Vice-President for Business Affairs for a copy of the audited Financial Statements; and the Director of Human Resource for the number of employees' and faculty evaluation result which were utilized as secondary data. For the primary data, the researcher prepared copies of the questionnaires and administered them to the administrators and employees and other stakeholders of the University after securing the participants' informed consent.

\section{Data Analysis}

The data obtained were tallied and treated using the following statistical tools:

A five-point Likert Scale was used to determine the participants' assessment on the internal processes, learning and innovation and customer's perspective of the balanced scorecard.

\begin{tabular}{|l|l|}
\hline \multicolumn{1}{|c|}{ Scale } & \multicolumn{1}{c|}{ Descriptive Interpretation } \\
\hline $4.20-5.00$ & All the time \\
\hline $3.40-4.19$ & Oftentimes \\
\hline $2.60-3.39$ & Sometimes \\
\hline $1.80-2.59$ & Rarely \\
\hline $1.00-1.79$ & Seldom \\
\hline $0-.99$ & Not at all \\
\hline
\end{tabular}

A three-point Scale for Interpreting Participants' Faculty Evaluation of St. Paul University Philippines.

\begin{tabular}{|l|l|l|}
\hline Range of Values & Qualitative Description & Legend \\
\hline $2.40-3.00$ & Excellent & $\mathrm{E}$ \\
\hline $1.80-2.39$ & Very Satisfactory & VS \\
\hline $1.20-1.79$ & Satisfactory & $\mathrm{S}$ \\
\hline $0.6-1.19$ & Unsatisfactory & US \\
\hline $0-.59$ & Very Unsatisfactory & VUS \\
\hline
\end{tabular}




\section{RESULTS AND DISCUSSION}

\section{St. Paul University Philippines' Profile}

SPUP has been operating for 113 years (1907-2020). SPUP has been operating for more than a century old serving the people of Region II and nearby communities.

Table 1. Number of employees

Table 1 Number of Employees for the past three years

\begin{tabular}{|l|c|c|c|}
\hline $\begin{array}{c}\text { School/Academic } \\
\text { Year }\end{array}$ & 2015-2016 & 2016-2017 & 2017-2018 \\
\hline SASTE & 32 & 33 & 34 \\
\hline SBAHM & 18 & 19 & 19 \\
\hline SITE & 11 & 7 & 37 \\
\hline SNASH & 35 & 43 & 7 \\
\hline CF & 9 & 8 & $\mathbf{1 0 4}$ \\
\hline TOTAL & $\mathbf{1 0 5}$ & $\mathbf{1 1 1}$ & \\
\hline
\end{tabular}

The above table presents the number of full-time faculty employees which includes the School of Arts, Sciences and Teacher Education (SASTE), School of Business, Accountancy and Hospitality Management (SBAHM), School of Information, Technology and Engineering (SITE), School of Nursing and Allied Health Sciences (SNAHS) and Christian Formation (CF) as of AY 2015-2016 to AY 2017-2018. The table reveal that there was a total of 105 full-time faculty in the tertiary in 2015-2016, 111 in 2016-2017 and 104 in 2017-2018 respectively.

Table 2 Three-Year Comparative Enrolment Profile from AY 2015-2016 to A.Y. 20182019

\begin{tabular}{|l|c|c|c|}
\hline School Year & $\mathbf{2 0 1 5 - 2 0 1 6}$ & $\mathbf{2 0 1 6 - 2 0 1 7}$ & $\mathbf{2 0 1 7 - 2 0 1 8}$ \\
\hline $\begin{array}{l}\text { Total number } \\
\text { of enrollees }\end{array}$ & 6,273 & 7,047 & 7,755 \\
\hline
\end{tabular}

The above table shows the comparative enrollment profile as of AY 2015-2016 to AY 2017-2018. The data reveal that enrollment has increased by 774 or $12.34 \%$ in 2016-2017 and 708 or $10.05 \%$ in $2017-2018$ respectively. This implies that SPUP has an effective in attracting students to enroll in the University. 
Table 3. Mean and descriptive interpretation of the Faculty Performance Evaluation by the Dean, Associate Dean/Program Coordinator, Students and Peer for AY. 2015-2016 to AY 2017-2018

\begin{tabular}{|c|c|c|c|c|c|c|}
\hline $\begin{array}{l}\text { Academic } \\
\text { Year }\end{array}$ & $\begin{array}{l}2015- \\
2016\end{array}$ & \multirow{2}{*}{$\begin{array}{l}\text { Descriptiv } \\
\text { e } \\
\text { Interpretat } \\
\text { ion }\end{array}$} & 2016-2017 & \multirow[t]{2}{*}{$\begin{array}{l}\text { Descriptive } \\
\text { Interpretation }\end{array}$} & $2017-2018$ & \multirow[t]{2}{*}{$\begin{array}{l}\text { Descriptive } \\
\text { Interpretation }\end{array}$} \\
\hline SCHOOL & Mean & & Mean & & Mean & \\
\hline SBAHM & 2.29 & VS & 2.45 & $E$ & 2.48 & $E$ \\
\hline SASTE & 2.39 & VS & 2.23 & VS & 2.35 & VS \\
\hline SITE & 2.10 & VS & - & - & - & - \\
\hline SNAHS & 2.32 & VS & 2.50 & $E$ & 2.66 & $E$ \\
\hline $\begin{array}{l}\text { Overall } \\
\text { Mean }\end{array}$ & 2.28 & VS & 2.39 & VS & 2.50 & $E$ \\
\hline
\end{tabular}

Table 3 presents the faculty performance evaluation by the dean, associate dean/program coordinator, students and peer for AY 2015-2016 to 2017-2018. It is shown in the table that in 2015-2016, college faculty evaluation has an overall mean of 2.28 and with a descriptive interpretation of very satisfactory. Furthermore, in 20162017, the SBAHM and SNAHS faculty performance evaluation have a weighted mean of 2.45 and 2.50 respectively having a descriptive interpretation of Excellent, while the SASTE faculty have a weighted mean of 2.23 or very satisfactory. However, in 20172018, SBAHM and SNAHS faculty were evaluated as Excellent. The SITE has no evaluation result from students, hence, there were no input during AY 2016-2017 and 2017-2028. The results manifest high quality of teaching and learning because of a strong faculty profile.

Table 4. Frequency and Percentage Rate of College Faculty Turnover as of AY 20152016 to $2017-2018$

\begin{tabular}{|l|c|c|c|c|c|c|}
\hline \multirow{2}{*}{ SCHOOL } & \multicolumn{2}{|l|}{$2015-2016$} & \multicolumn{2}{l|}{$2016-2017$} & $2017-2018$ \\
\cline { 2 - 7 } & $f$ & $\%$ & $f$ & $\%$ & $f$ & $\%$ \\
\hline SASTE & 3 & 23.08 & 2 & 12.5 & 3 & 23.08 \\
\hline SBAHM & 4 & 30.77 & 2 & 12.5 & 4 & 30.77 \\
\hline SNAHS & 1 & 7.69 & 9 & 56.25 & 1 & 7.69 \\
\hline SITE & 3 & 23.08 & 1 & 6.25 & 3 & 23.08 \\
\hline CF & 2 & 15.38 & 2 & 12.5 & 2 & 15.38 \\
\hline
\end{tabular}




\begin{tabular}{|l|c|c|c|c|c|c|}
\hline TOTAL & 13 & 100 & 16 & 100 & 13 & 100 \\
\hline No. of Faculty & 105 & 14.29 & 111 & 14.41 & 105 & 14.29 \\
\hline
\end{tabular}

The above table presents the rate of turn-over among college faculty during AY 2015-2016 to 2017-2018. It is evident in the table that there were 13 or 14.29 percent college faculty who resigned from the University in 2015-2016, 16 or 14.41 percent in 2016-2017 and 13 or 14.29 percent in 2017-2018. It further reveals that there was a decreasing rate of full - time faculty who resigned from the University since 2015-2016 to 2017-2018. The data imply that full-time college faculty of SPUP are happy and satisfied with their teaching ministry in the University as manifested with the decreasing rate of turn over

\section{SPUP Performance in the Balanced Scorecard}

\subsection{Internal business processes}

Table 5 to Table 9 are the perceptions of the participants on the internal business process of the University.

Table 5. Mean and descriptive interpretation of the participants' assessment on the basic process aspect of the Internal Process of SPUP's Balanced Scorecard

\begin{tabular}{|l|c|c|}
\hline \multicolumn{1}{|c|}{ Statement } & Mean & $\begin{array}{c}\text { Descriptive } \\
\text { Interpretation }\end{array}$ \\
\hline $\begin{array}{l}\text { SPUP has control over the quality of services offered to } \\
\text { clients. }\end{array}$ & 4.02 & Oftentimes \\
\hline $\begin{array}{l}\text { SPUP measures objectively performance through } \\
\text { analysis of reports and transactions. }\end{array}$ & 4.02 & Oftentimes \\
\hline $\begin{array}{l}\text { Quality system is monitored, audited and evaluated } \\
\text { SPUP considers trend analysis and other statistical tools } \\
\text { in planning and decision making. }\end{array}$ & 3.82 & Oftentimes \\
\hline $\begin{array}{l}\text { There is a comparison of the quality of work in the } \\
\text { current period with that of previous years. }\end{array}$ & 3.87 & Oftentimes \\
\hline $\begin{array}{l}\text { There is a basis for the processing of performance } \\
\text { measurement. }\end{array}$ & 3.84 & Oftentimes \\
\hline $\begin{array}{l}\text { SPUP presents reports and analysis of reports to the } \\
\text { employees for continuous improvement. }\end{array}$ & 3.83 & Oftentimes \\
\hline $\begin{array}{l}\text { The documents are available when needed, accurate } \\
\text { and accessible at all times. }\end{array}$ & 3.91 & \\
\hline
\end{tabular}




\begin{tabular}{|l|c|c|}
\hline $\begin{array}{l}\text { There is a standard set regarding performance } \\
\text { measurement and compared with actual performance. }\end{array}$ & 3.71 & Oftentimes \\
\hline $\begin{array}{l}\text { Variance analysis between the two are done for } \\
\text { verification. }\end{array}$ & 3.78 & Oftentimes \\
\hline $\begin{array}{l}\text { All employees are aware of the performance standards } \\
\text { and measurements of the SPUP. }\end{array}$ & 3.78 & Oftentimes \\
\hline $\begin{array}{l}\text { The rules and procedures in SPUP specify how the task } \\
\text { within departments is to be done. }\end{array}$ & 3.84 & Oftentimes \\
\hline $\begin{array}{l}\text { Key results or areas are clearly identified, communicated } \\
\text { and evaluated to determine the performance of the units } \\
\text { of SPUP }\end{array}$ & 3.80 & Oftentimes \\
\hline $\begin{array}{l}\text { SPUP has some policies that at some points complicate } \\
\text { the processes. }\end{array}$ & 3.81 & Seldom \\
\hline $\begin{array}{l}\text { Some policies and processes are conflicting and create } \\
\text { confusion in the operations. }\end{array}$ & 1.00 & Oftentimes \\
\hline Category Mean & 3.66 & \\
\hline
\end{tabular}

Table 5 reveals that SPUP oftentimes implements its internal processes with a category mean of 3.45. It is also revealed in the table that SPUP oftentimes control the quality of services offered to clients and measures objectively performance through analysis of reports and transactions with the highest mean of 4.02 . This is followed by considering trend analysis and other statistical tools in planning and decision making with a mean of 3.96. The item on "SPUP has some policies that at some points complicate the processes" was perceived by the participants as oftentimes having a weighted mean of 3.81. Finally, some policies and processes are seldom conflicting and create confusion in the operations with a mean of 1.00. In general, SPUP has oftentimes demonstrated the basic process aspect of the Internal Process of the balanced scorecard.

Table 6. Mean and descriptive interpretation of the participants' assessment on the technology and information effectiveness' aspect of the Internal Process of SPUP's Balanced Scorecard

\begin{tabular}{|l|c|c|}
\hline \multicolumn{1}{|c|}{ Statement } & Mean & $\begin{array}{c}\text { Descriptive } \\
\text { Interpretation }\end{array}$ \\
\hline $\begin{array}{l}\text { Everybody is aware of the quality management } \\
\text { system }\end{array}$ & 3.87 & Oftentimes \\
\hline $\begin{array}{l}\text { Information systems used in SPUP are effective } \\
\text { and user-friendly for employees and other users. }\end{array}$ & 3.87 & Oftentimes \\
\hline $\begin{array}{l}\text { Information system of SPUP is always available } \\
\text { and adequate. }\end{array}$ & 3.83 & Oftentimes \\
\hline $\begin{array}{l}\text { SPUP have a documented system of procedures. } \\
\text { SPUP operates an electronic document filing }\end{array}$ & 3.77 & Oftentimes \\
\hline
\end{tabular}




\begin{tabular}{|l|c|c|}
\hline system through a document management system. & & \\
\hline $\begin{array}{l}\text { There is a data base system for SPUP's } \\
\text { personnel. }\end{array}$ & 3.82 & Oftentimes \\
\hline $\begin{array}{l}\text { There is information system for students and } \\
\text { customers. }\end{array}$ & 3.74 & Oftentimes \\
\hline $\begin{array}{l}\text { There is a separate office who takes care of the } \\
\text { marketing and promotions of SPUP. }\end{array}$ & 3.78 & Oftentimes \\
\hline $\begin{array}{l}\text { SPUP operates an effective system so that } \\
\text { client's unpaid balance can be determined. }\end{array}$ & 3.71 & Oftentimes \\
\hline Category Mean & $\mathbf{3 . 8 1}$ & Oftentimes \\
\hline
\end{tabular}

It is evident in Table 6 that SPUP oftentimes considered the use of technology and information in its internal processes with a total mean of 3.81. In addition, everybody is aware of the quality management system and that the information systems used in SPUP are effective and user-friendly for employees and other users having the highest mean of 3.87. Moreover, SPUP oftentimes operates an effective system so that client's unpaid balance can be determined having the lowest mean of 3.71. The data imply that SPUP endeavors to provide best technology and ensure the effectiveness of its information to all its clients. 
Table 7 Mean and descriptive interpretation of the participants' assessment on Employee process issues of the Internal Process of SPUP's Balanced Scorecard

\begin{tabular}{|c|c|c|}
\hline Statement & Mean & $\begin{array}{l}\text { Descriptive } \\
\text { Interpretation }\end{array}$ \\
\hline Employees are knowledgeable of their jobs. & 3.98 & Oftentimes \\
\hline Employees are aware of their job descriptions. & 3.98 & Oftentimes \\
\hline $\begin{array}{l}\text { Standards and expectations for performance are discussed } \\
\text { with the employees. }\end{array}$ & 3.97 & Oftentimes \\
\hline $\begin{array}{l}\text { Employees are informed on the results of their } \\
\text { performance evaluation periodically. }\end{array}$ & 3.97 & Oftentimes \\
\hline $\begin{array}{l}\text { There are upward mobility or promotion for high performing } \\
\text { employees in SPUP. }\end{array}$ & 3.77 & Oftentimes \\
\hline $\begin{array}{l}\text { There is low turn- over of employees or employees rarely } \\
\text { resign from work. }\end{array}$ & 3.62 & Oftentimes \\
\hline Category Mean & 3.19 & Oftentimes \\
\hline
\end{tabular}

Table 7 reveals that SPUP oftentimes sustain its internal processes with category mean of 3.19. Furthermore, employees are knowledgeable in their job as well as employees being aware of their job descriptions with the highest mean of 3.98. This was followed by the practice of SPUP where standards and expectations for performance are discussed with the employees and informing them with their performance evaluation results periodically with a mean of 3.97. The statement "there is low turn- over of employees or employees rarely resign from work" has the lowest mean of 3.62 and with a descriptive interpretation of oftentimes. 
Table 8. Mean and descriptive interpretation of the participants' assessment on the research aspect of the Internal Process of SPUP's Balanced Scorecard

\begin{tabular}{|c|c|c|}
\hline Statement & Mean & $\begin{array}{l}\text { Descriptive } \\
\text { Interpretation }\end{array}$ \\
\hline $\begin{array}{l}\text { SPUP has offered new courses/services for the past } \\
\text { three years }\end{array}$ & 4.01 & Oftentimes \\
\hline $\begin{array}{l}\text { Employees' research, creative work/output are given } \\
\text { substantial support and recognition. }\end{array}$ & 4.01 & Oftentimes \\
\hline $\begin{array}{l}\text { There is a separate office for research and publication in } \\
\text { SPUP. }\end{array}$ & 3.94 & Oftentimes \\
\hline $\begin{array}{l}\text { SPUP allocates budget for project development and } \\
\text { innovation. }\end{array}$ & 3.94 & Oftentimes \\
\hline $\begin{array}{l}\text { Employees are encouraged to participate in innovative } \\
\text { processes through research. }\end{array}$ & 3.81 & Oftentimes \\
\hline $\begin{array}{l}\text { Other schools benchmarked from SPUP for its innovative } \\
\text { programs. }\end{array}$ & 3.81 & Oftentimes \\
\hline $\begin{array}{l}\text { Research policies and procedures are effective and } \\
\text { supportive of the researchers or prospective researchers. }\end{array}$ & 3.80 & Oftentimes \\
\hline $\begin{array}{l}\text { Research, creative work and innovation are funded and } \\
\text { implemented }\end{array}$ & 3.78 & Oftentimes \\
\hline $\begin{array}{l}\text { Giving of research incentives encourage employees to } \\
\text { do research. }\end{array}$ & 3.76 & Oftentimes \\
\hline $\begin{array}{l}\text { Research work results to innovative products or services } \\
\text { offered in SPUP.; }\end{array}$ & 3.70 & Oftentimes \\
\hline $\begin{array}{l}\text { Research, creative work and innovation are copyrighted } \\
\text { or patented }\end{array}$ & 3.68 & Oftentimes \\
\hline Category Mean & 3.62 & Oftentimes \\
\hline
\end{tabular}

Table 8 reveals that SPUP oftentimes practice its internal process in research with a category mean of 3.62. It further reveals that SPUP oftentimes give employees' research, creative work/output substantial support and recognition; offered new courses/services for the past three years with the highest mean of 4.01. The statement "Research, creative work and innovation are oftentimes copyrighted or patented" has the lowest mean of 3.68. Overall, SPUP oftentimes demonstrated its internal process on research in the Balanced Scorecard. 
Summary Table on the Extent of Demonstration of SPUP on the Basic Process, Technology and Information effectiveness, Employee Process Issues and Research

Table 9 shows the extent of demonstration of SPUP on the internal processes of the balanced scorecard.

Table 9. SPUP's Extent of Demonstration on the Internal Processes of the Balanced Scorecard

\begin{tabular}{|l|c|c|}
\hline INTERNAL PROCESSES & Mean & Descriptive Interpretation \\
\hline Basic process & 3.66 & Oftentimes \\
\hline $\begin{array}{l}\text { Technology and information } \\
\text { effectiveness }\end{array}$ & 3.81 & Oftentimes \\
\hline Employee process issues & 3.19 & Sometimes \\
\hline Research & 3.62 & Oftentimes \\
\hline Category Mean & $\mathbf{3 . 5 2}$ & Oftentimes \\
\hline
\end{tabular}

The mean ratings as reflected in table 9 reveals that 'oftentimes' SPUP has demonstrated in the internal processes along with areas on basic process, technology and information effectiveness and research; and "sometimes" along the employee process issues.

2.2 learning and growth perspective;

Learning and Growth covers the extent to which the training and innovations promote efficiency and effectiveness. Table 10 to Table 17 are the assessments of the participants on the trainings provided by the University for its employees. 
Table 10. Mean and descriptive interpretation of the participants' assessment on the training aspect of the Learning and Growth Perspective of SPUP's Balanced Scorecard

\begin{tabular}{|l|c|c|}
\hline Statement & Mean & Descriptive Interpretation \\
\hline $\begin{array}{l}\text { SPUP organizes in-house training programs } \\
\text { referring for the development of the employees' } \\
\text { skills. }\end{array}$ & 4.05 & Oftentimes \\
\hline $\begin{array}{l}\text { SPUP provides opportunities for its employees } \\
\text { to participate in training courses in order to learn } \\
\text { new strategies. }\end{array}$ & 3.97 & Oftentimes \\
\hline $\begin{array}{l}\text { St. Paul University Philippines' employees are } \\
\text { provided with training on how to handle and deal } \\
\text { with issues and problems of the customers. }\end{array}$ & 3.82 & Oftentimes \\
\hline $\begin{array}{l}\text { SPUP has a training package for new } \\
\text { employees. }\end{array}$ & 3.78 & Oftentimes \\
\hline $\begin{array}{l}\text { Training opportunities given to employees are } \\
\text { based from Training need assessment and } \\
\text { Training Roadmaps }\end{array}$ & 3.75 & Oftentimes \\
\hline $\begin{array}{l}\text { SPUP employees are sent for seminars and } \\
\text { other training programs that they need in their } \\
\text { work. }\end{array}$ & 3.56 & Oftentimes \\
\hline Category Mean & 3.81 & Oftentimes \\
\hline
\end{tabular}

Table 10 reveals that training is oftentimes provided by SPUP with a category mean of 3.81. It further reveals that the University organizes in-house training programs referring for the development of the employees' skills with the highest mean of 4.05 , followed by the provision of training on how to handle and deal with issues and problems of the customers with a mean of 3.97. On the other hand, the participants claimed that all SPUP employees are oftentimes sent for seminars and other training programs that they need in their work having the lowest mean of 3.56. The data imply that SPUP oftentimes provided trainings to its employees for their professional growth and development. 


\section{2 learning and growth perspective}

\section{Opportunity Empowered}

Table 11 Mean and descriptive interpretation of the participants' assessment on the Opportunity Empowered aspect of the Learning and Growth Perspective of SPUP's Balanced Scorecard

\begin{tabular}{|c|c|c|}
\hline Statement & Mean & Descriptive Interpretation \\
\hline $\begin{array}{l}\text { SPUP employees are given opportunity to develop } \\
\text { solutions and strategies to solve problems within their } \\
\text { level. }\end{array}$ & 3.82 & Oftentimes \\
\hline There are open opportunities for knowledge sharing. & 3.80 & Oftentimes \\
\hline $\begin{array}{l}\text { The employees are supported by the administration to } \\
\text { develop best practices and try-out or experiment on it. }\end{array}$ & 3.72 & Oftentimes \\
\hline $\begin{array}{l}\text { SPUP encourages the employees to produce new ideas } \\
\text { concerning the growth of the organization. }\end{array}$ & 3.71 & Oftentimes \\
\hline $\begin{array}{l}\text { There are incentives/recognition to employees for } \\
\text { innovative ideas and best practices. }\end{array}$ & 3.68 & Oftentimes \\
\hline $\begin{array}{l}\text { The employees are encouraged to make } \\
\text { recommendations or proposal which can be helpful to } \\
\text { the organization. }\end{array}$ & 3.64 & Oftentimes \\
\hline $\begin{array}{l}\text { There is open communication for employees to express } \\
\text { their knowledge. }\end{array}$ & 3.58 & Oftentimes \\
\hline Category Mean & 3.71 & Oftentimes \\
\hline
\end{tabular}

Table 11 shows the participants' assessment on the learning and growth perspective of the balance scorecard particularly on employee empowerment. The data reveal that SPUP oftentimes provide employees opportunities to be empowered having a category mean of 3.71. Furthermore, SPUP employees are given opportunities to develop solutions and strategies to solve problems within their level having the highest mean of 3.82, followed by the open opportunities for knowledge sharing with a mean of 3.80. Moreover, the participants perceived that the opportunity for open communication to express their knowledge is oftentimes demonstrated in SPUP having the lowest mean of 3.58. The data imply that the University oftentimes develop its employees by giving opportunities to learn and grow in their skills, talents and abilities. 
Table 12. Mean and descriptive interpretation of the participants' assessment on the Communications within SPUP of the Learning and Growth Perspective of SPUP's Balanced Scorecard

\begin{tabular}{|c|c|c|}
\hline Statement & Mean & Descriptive Interpretation \\
\hline $\begin{array}{l}\text { There is an opportunity for SPUP employees to share } \\
\text { their knowledge and expertise. }\end{array}$ & 3.79 & Oftentimes \\
\hline $\begin{array}{l}\text { SPUP administrators creates open line of communication } \\
\text { with the employees for new ideas, innovations and best } \\
\text { practices to be expressed. }\end{array}$ & 3.71 & Oftentimes \\
\hline Collaboration of ideas are encouraged and implemented. & 3.66 & Oftentimes \\
\hline There is an open line of communication across units. & 3.62 & Oftentimes \\
\hline $\begin{array}{l}\text { There is regular forum for expression of ideas to improve } \\
\text { work practices. }\end{array}$ & 3.61 & Oftentimes \\
\hline $\begin{array}{l}\text { Other unit welcome opportunities to share their best } \\
\text { practices with other units. }\end{array}$ & 3.59 & Oftentimes \\
\hline Category Mean & 3.66 & Oftentimes \\
\hline
\end{tabular}

Table 12 reveals that SPUP oftentimes considered the importance of communication in the University with category mean of 3.66. Furthermore, the data reveal that there was an opportunity for SPUP employees to share their knowledge and expertise with the highest mean of 3.79. This was followed by the fact that SPUP administrators create an open line of communication with the employees for new ideas, innovations and best practices to be expressed with a mean of 3.71. However, other units oftentimes welcome opportunities to share their best practices with other units with the lowest mean of 3.59. The data imply that communication within SPUP is oftentimes practiced as a tool to enhanced learning. 
Table 13. Mean and descriptive interpretation of the participants' assessment on the Reward policy to encourage performance aspect of the Learning and Growth Perspective of SPUP's Balanced Scorecard

\begin{tabular}{|l|c|c|}
\hline \multicolumn{1}{|c|}{ Statement } & Mean & $\begin{array}{l}\text { Descriptive } \\
\text { Interpretation }\end{array}$ \\
\hline $\begin{array}{l}\text { There is recognition for excellent performance } \\
\text { of the team or unit. }\end{array}$ & 3.57 & Oftentimes \\
\hline Recognitions are given for new best practices. & 3.56 & Oftentimes \\
\hline $\begin{array}{l}\text { Employees' performance evaluation is based } \\
\text { on new knowledge innovative or best practices } \\
\text { contributed to the University. }\end{array}$ & 3.49 & Oftentimes \\
\hline $\begin{array}{l}\text { Reward system is sufficient to encourage } \\
\text { employees to be more productive. }\end{array}$ & 3.46 & Oftentimes \\
\hline $\begin{array}{l}\text { Employees are rewarded and promoted based } \\
\text { on their new innovative ideas }\end{array}$ & 3.45 & Oftentimes \\
\hline Category Mean & 3.51 & \\
\hline
\end{tabular}

Table 13 reveals that SPUP oftentimes encourage performance through giving rewards with a category mean of 3.51. Furthermore, participants believed that there is oftentimes recognition for excellent performance of the team or unit with a mean of 3.57 followed by recognition are given for new best practices with a mean of 3.56 . Moreover, employees are rewarded and promoted based on their new innovative ideas was assessed by the participants with the lowest mean of 3.45. This implies that SPUP is striving to consider rewarding its employees so as to encourage excellent performance as perceived by the participants. 
Table 14. Mean and descriptive interpretation of the participants' assessment on the Benchmarking for New ldeas aspect of the Learning and Growth Perspective of the Balanced Scorecard

\begin{tabular}{|l|c|c|}
\hline \multicolumn{1}{|c|}{ Statement } & Mean & Descriptive Interpretation \\
\hline $\begin{array}{l}\text { When coming across problems, SPUP tends to consider } \\
\text { experiences of other units and similar institution in } \\
\text { solving problems. }\end{array}$ & 3.60 & Oftentimes \\
\hline $\begin{array}{l}\text { Benchmarking results are processed and used as basis } \\
\text { in the development of procedures and policies in the } \\
\text { University. }\end{array}$ & 3.60 & Oftentimes \\
\hline $\begin{array}{l}\text { Benchmarking results are discussed and shared in a } \\
\text { meeting or conference. }\end{array}$ & 3.51 & Oftentimes \\
\hline $\begin{array}{l}\text { Administration encourages employees to organize } \\
\text { benchmarking activities. }\end{array}$ & 3.46 & Oftentimes \\
\hline $\begin{array}{l}\text { There are regular opportunities for employees to } \\
\text { benchmark best practices from institutions. }\end{array}$ & 3.42 & Oftentimes \\
\hline Category Mean & 3.50 & \\
\hline
\end{tabular}

It is gleaned in the table above that benchmarking for new ideas is oftentimes practiced by SPUP with a category mean of 3.50. It further reveals that when coming across problems, SPUP oftentimes tends to consider experiences of other units and similar institution in solving problems and also processed and used benchmarking results as basis in the development of procedures and policies in the University having a mean of 3.60. On the other hand, the participants considered the regular opportunities for employees to benchmark best practices from institutions as oftentimes practiced with the lowest mean of 3.42. The data imply that benchmarking is oftentimes practiced in SPUP in its desire to enhanced learning and professional growth among its employees. 
Table 15. Mean and descriptive interpretation of the participants' assessment on the mentorship aspect of the Learning and Growth Perspective of SPUP's Balanced Scorecard

\begin{tabular}{|l|c|c|}
\hline \multicolumn{1}{|c|}{ Statement } & Mean & $\begin{array}{c}\text { Descriptive } \\
\text { Interpretation }\end{array}$ \\
\hline Senior employee mentors the junior employees. & 3.57 & Oftentimes \\
\hline $\begin{array}{l}\text { Mentors are trained how to effectively mentor the junior } \\
\text { employees. }\end{array}$ & 3.15 & Sometimes \\
\hline $\begin{array}{l}\text { There are incentives or recognitions given to employees } \\
\text { mentoring the new faculty. }\end{array}$ & 3.02 & Sometimes \\
\hline $\begin{array}{l}\text { There are policies and system for mentorship } \\
\text { implemented. }\end{array}$ & 2.95 & Sometimes \\
\hline Category Mean & $\mathbf{3 . 2 1}$ & \\
\hline
\end{tabular}

Table 15 reveals that mentorship was sometimes considered by SPUP in developing the learning and growth of its employees with a category mean of 3.21 . It further shows that senior employees oftentimes mentor the junior employees with a mean of 3.57, followed by mentors are trained how to effectively mentor the junior employees at times with a mean of 3.15. Sometimes, there are policies and system for mentorship implemented having the lowest mean of 2.95. These imply that mentorship was considered by SPUP in the learning and growth perspective of the balanced scorecard.

Table 16. Mean and descriptive interpretation of the participants' assessment on the Best Practice aspect of the Learning and Growth Perspective of SPUP's Balanced Scorecard

\begin{tabular}{|l|c|c|}
\hline \multicolumn{1}{|c|}{ Statement } & Mean & Descriptive \\
Interpretation
\end{tabular}




\begin{tabular}{|l|c|c|}
\hline $\begin{array}{l}\text { Quality circles are formed to discuss regularly ways to } \\
\text { improve processes and procedures. }\end{array}$ & 3.55 & Oftentimes \\
\hline Authors of best practices are rewarded or recognized. & 3.44 & Oftentimes \\
\hline Category Mean & 3.48 & Oftentimes \\
\hline
\end{tabular}

Table 17 reveals that SPUP oftentimes has the best practice for its employees' learning and growth with an category mean of 3.48. The vision-mission and goal strategy focused on creativity and innovation to all departments has the highest mean of 3.86 together with employees are given opportunities to share individual's best practices. However, authors of best practices are oftentimes rewarded or recognized with the lowest mean of 3.44. The data imply that SPUP has demonstrated its best practice in the learning and growth of its employees.

Table 18 Summary Table on Learning and Growth Perspective of the Balanced Scorecard of SPUP

\begin{tabular}{|l|c|c|}
\hline LEARNING and GROWTH & Mean & $\begin{array}{c}\text { Descriptive } \\
\text { Interpretation }\end{array}$ \\
\hline Training & $\mathbf{3 . 8 1}$ & Oftentimes \\
\hline Opportunity to be empowered & $\mathbf{3 . 7 1}$ & Oftentimes \\
\hline Communications within SPUP & $\mathbf{3 . 6 6}$ & Oftentimes \\
\hline $\begin{array}{l}\text { Reward policy to encourage } \\
\text { performance }\end{array}$ & $\mathbf{3 . 5 1}$ & Oftentimes \\
\hline Benchmarking for New ldeas & $\mathbf{3 . 5 0}$ & Oftentimes \\
\hline Best Practice & $\mathbf{3 . 4 8}$ & Oftentimes \\
\hline Mentorship & $\mathbf{3 . 2 1}$ & Sometimes \\
\hline Category Mean & $\mathbf{3 . 5 5}$ & Oftentimes \\
\hline
\end{tabular}

Table 18 shows the summary of the participants' assessment on the learning and growth aspect of the balanced scorecard of St. Paul University Philippines. The data reveal that the participants oftentimes agreed that SPUP provided training to its employees with an overall mean of 3.55 . 
Table 19. Increases or Decreases in the Statement of Comprehensive Income for the years ended May 31, 2016 to 2018 Using 2016 as the Base Year

\begin{tabular}{|c|c|c|c|}
\hline \multirow[t]{2}{*}{ ACADEMIC YEAR } & \multicolumn{3}{|c|}{ Percent Increase } \\
\hline & 2016 & 2017 & 2018 \\
\hline \multicolumn{4}{|l|}{ REVENUES FROM SCHOOL OPERATIONS } \\
\hline Tuition and Other Fees & 100 & 5.26 & 11.91 \\
\hline Student Services & 100 & 4.52 & 8.45 \\
\hline $\begin{array}{lll}\text { TOTAL REVENUE } & \text { FROM } & \text { SCHOOL } \\
\text { OPERATIONS } & & \end{array}$ & 100 & 5.07 & 11.041 \\
\hline \multicolumn{4}{|c|}{ NET REVENUES FROM SCHOOL RELATED ACTIVITIES } \\
\hline Auxiliary services & 100 & $63.96 \%$ & $533.51 \%$ \\
\hline Interest income and surcharges & 100 & $8.70 \%$ & $(.06 \%)$ \\
\hline Others & 100 & $63.53 \%$ & $73.15 \%$ \\
\hline $\begin{array}{l}\text { TOTAL REVENUE FROM SCHOOL RELATED } \\
\text { ACTIVITIES }\end{array}$ & 100 & $81.07 \%$ & $159.53 \%$ \\
\hline OTHER COMPREHENSIVE INCOME & & 0 & 0 \\
\hline TOTAL REVENUES & & $29.22 \%$ & $56.86 \%$ \\
\hline \multicolumn{4}{|l|}{ EXPENSES FOR SCHOOL OPERATIONS } \\
\hline Salaries and other related expenses & 100 & $24.40 \%$ & $45.63 \%$ \\
\hline Student services & 100 & $4.47 \%$ & $6.64 \%$ \\
\hline Depreciation & 100 & $4.00 \%$ & $24.58 \%$ \\
\hline General and administrative expenses & 100 & $8.55 \%$ & $25.06 \%$ \\
\hline Utilities and supplies & 100 & $5.61 \%$ & $35.49 \%$ \\
\hline Scholarship and discounts & 100 & $42.98 \%$ & $79.32 \%$ \\
\hline TOTAL EXPENSES & 100 & $15.74 \%$ & $34.25 \%$ \\
\hline NET EXPENSE FROM SCHOOL OPERATIONS & 100 & 0 & 0 \\
\hline TOTAL COMPREHENSIVE & & & \\
\hline INCOME (LOSS) & 100 & $124.86 \%$ & $217.23 \%$ \\
\hline
\end{tabular}

Table 19 shows the comprehensive income of SPU using trend analysis. The data reveal that SPUP derives mostly its revenues from tuition and other fees. An 
increasing trend is revealed in the table, hence, there was a net increase of comprehensive income from $124.86 \%$ in 2017 to $217.23 \%$ in 2018 . The data imply that in terms of revenue, the University is performing well.

Table 20. Vertical Analyis of the Financial Statement

\begin{tabular}{|c|c|c|c|}
\hline ACADEMIC YEAR & 2016 & 2017 & 2018 \\
\hline REVENUES FROM SCHOOL OPERATIONS & & & \\
\hline Tuition and Other Fees & $75.66 \%$ & $71.45 \%$ & $63.56 \%$ \\
\hline Student Services & $12.33 \%$ & $11.72 \%$ & $16.57 \%$ \\
\hline $\begin{array}{lll}\text { TOTAL REVENUE } & \text { FROM } & \text { SCHOOL } \\
\text { OPERATIONS } & & \end{array}$ & $87.99 \%$ & $83.17 \%$ & $80.12 \%$ \\
\hline $\begin{array}{l}\text { NET REVENUES FROM SCHOOL RELATED } \\
\text { ACTIVITIES }\end{array}$ & & & \\
\hline Auxiliary services & $2.35 \%$ & $4.80 \%$ & $9.50 \%$ \\
\hline Interest income and surcharges & $0.57 \%$ & $0.52 \%$ & $0.34 \%$ \\
\hline Others & $9.10 \%$ & $11.51 \%$ & $10.04 \%$ \\
\hline $\begin{array}{l}\text { TOTAL REVENUE FROM SCHOOL RELATED } \\
\text { ACTIVITIES }\end{array}$ & $12.01 \%$ & $16.83 \%$ & $19.88 \%$ \\
\hline OTHER COMPREHENSIVE INCOME & & & \\
\hline TOTAL REVENUES & & & \\
\hline EXPENSES FOR SCHOOL OPERATIONS & & & \\
\hline Salaries and other related expenses & $42.84 \%$ & $41.24 \%$ & $39.77 \%$ \\
\hline Student services & $13.55 \%$ & $10.96 \%$ & $9.21 \%$ \\
\hline Depreciation & $13.95 \%$ & $11.23 \%$ & $11.08 \%$ \\
\hline General and administrative expenses & $10.20 \%$ & $8.57 \%$ & $8.13 \%$ \\
\hline Utilities and supplies & $4.67 \%$ & $3.82 \%$ & $4.03 \%$ \\
\hline Scholarship and discounts & $2.43 \%$ & $2.68 \%$ & $2.77 \%$ \\
\hline TOTAL EXPENSES & $87.64 \%$ & $78.50 \%$ & $75.01 \%$ \\
\hline $\begin{array}{lll}\text { NET EXPENSE } & \text { FROM } & \text { SCHOOL } \\
\text { OPERATIONS } & & \end{array}$ & & & \\
\hline $\begin{array}{l}\text { TOTAL COMPREHENSIVE } \\
\text { INCOME (LOSS) }\end{array}$ & $12.36 \%$ & $21.50 \%$ & $24.99 \%$ \\
\hline
\end{tabular}


Table 20 presents the financial performance of the University during AY 2015-2016 to AY 2017-2018 using vertical analysis. It is evident that it has an increasing total comprehensive income during these three periods covered in this study.

Ratios:

A. Liquidity Ratios

Table 21. A.1 Current Ratio

\begin{tabular}{|l|c|c|c|}
\hline & $\mathbf{2 0 1 6}$ & $\mathbf{2 0 1 7}$ & $\mathbf{2 0 1 8}$ \\
\hline Liquidity Ratios & 0.92 & 0.64 & 0.86 \\
\hline Acid Test & 0.89 & 0.62 & 0.84 \\
\hline $\begin{array}{l}\text { Number of days collection } \\
\text { period }\end{array}$ & 120 days & 120 days & 120 days \\
\hline
\end{tabular}

The above table shows the performance of St. Paul University Philippines in terms of the ability for current assets to pay its current liabilities. The current ratios reveal that in general, the University is not liquid because of the number of days (120 days) collection period. This implies that policy on managing current assets is not so efficient.

Table 22. A.2 Cash Flow Liquidity Ratio

\begin{tabular}{|l|c|c|c|}
\hline & $\mathbf{2 0 1 6}$ & $\mathbf{2 0 1 7}$ & $\mathbf{2 0 1 8}$ \\
\hline Cash Flow Liquidity Ratio & 0.20 & 0.02 & 0.26 \\
\hline
\end{tabular}

The above table shows the performance of St. Paul University Philippines in terms of the capacity of its current assets to pay its current liabilities. The liquidity ratios reveal that the University had challenges in coping with the need to pay its current liabilities. This implies that working capital policy must be evaluated to improve the liquidity of the University. 


\section{B. Solvency/Leverage Ratios}

Table 23. Debt ratio

\begin{tabular}{|l|c|c|c|}
\hline & $\mathbf{2 0 1 6}$ & $\mathbf{2 0 1 7}$ & $\mathbf{2 0 1 8}$ \\
\hline Debt Ratio & $38 \%$ & $36 \%$ & $32 \%$ \\
\hline
\end{tabular}

The above ratio presents the effectiveness of SPUP in managing its liabilities over its total assets. The ratio reveals that $1 / 3$ of the total asset is financed by debt while $2 / 3$ was financed by equity, which is above the standard of .68 . This implies that the University is solvent and has been financing most of its investments internally.

Table 24. Long term Debt to Equity Ratio

\begin{tabular}{|l|c|c|c|}
\hline & 2016 & 2017 & 2018 \\
\hline $\begin{array}{l}\text { Long-Term Debt to Equity } \\
\text { Ratio }\end{array}$ & 0.61 & 0.55 & 0.48 \\
\hline
\end{tabular}

The above table shows the debt-ratio of the University. The data reveal that the University has improved its solvency status, as manifested by its decreasing trend from 2016 to 2018. The data reveal that in A.Y. 2016, 39\% of the total assets of the University was financed by debt, while $61 \%$ of it was financed by equity. With the increasing trend starting AY 2016 to AY 2018, the data imply that there were more assets of the University that were financed by equity rather than debt.

Table 25. Total Debt to Equity Ratio

\begin{tabular}{|l|c|c|c|}
\hline & 2016 & 2017 & 2018 \\
\hline Total Debt to Equity Ratio & $38 \%$ & $36 \%$ & $32 \%$ \\
\hline
\end{tabular}

The above ratios present the performance of the University in managing its total debt over its equity. The data reveal that the equity of the University is twice the total debt, hence, it is very solvent at the same time the administrators are conservative in generating debt to support its operation. 
Table 26. Accounts Receivable turnover

\begin{tabular}{|l|c|c|c|}
\hline & 2016 & 2017 & 2018 \\
\hline $\begin{array}{l}\text { Accounts Receivable } \\
\text { turnover }\end{array}$ & 2.725 & 2.888 & 3.096 \\
\hline Days of Turnover & 134 days & 127 days & 116 days \\
\hline
\end{tabular}

The above table reveals the effectiveness of SPUP in managing its receivables. As a rule of thumb, the higher the turnover ratio, the more effective is the University's cash collection management. SPUP has improved its accounts receivable collection as evidenced by decreasing days of receivable and increasing accounts receivable turnover. Though there are improvements, it is also important to analyze that the days of collection met by the University is beyond the usual collection period of 40 days. Every term such as Prelims, Midterms and Finals is 40 days gap. Every end of the term usually is the required period of collection. The table reveals that SPUP's days of collection is beyond 40 days. This leads SPUP to a problem in liquidity as cash collection can not be met on time for payment of current liabilities.

Table 27. Fixed Assets Turnover

\begin{tabular}{|l|c|c|c|}
\hline & $\mathbf{2 0 1 6}$ & $\mathbf{2 0 1 7}$ & $\mathbf{2 0 1 8}$ \\
\hline Fixed Assets Turnover & 0.108 & 0.150 & 0.082 \\
\hline
\end{tabular}

The above table shows the effectiveness of SPUP in utilizing its property, plant and equipment. As a rule of thumb, to be considered effective, it should be at least 0.30 times (Tugas, 2012). The University fixed assets turnover was below the standard which imply that SPUP has a great challenge in utilizing fixed assets.

Table 28. Total assets turnover

\begin{tabular}{|l|c|c|c|}
\hline & $\mathbf{2 0 1 6}$ & $\mathbf{2 0 1 7}$ & $\mathbf{2 0 1 8}$ \\
\hline Total assets turnover & 0.394 & 0.434 & 0.487 \\
\hline
\end{tabular}


The ratios above show the performance of the University 's total assets turnover. It is evident in the table that management has an increasing total assets turnover in 2016 to 2018. This implies efficient asset management since it was higher than the standard of 0.30 times (Tugas, 2012).

D. Profitability Ratio

Table 29. Basic Earning Power Ratio

\begin{tabular}{|l|l|l|l|}
\hline & 2016 & 2017 & 2018 \\
\hline $\begin{array}{l}\text { Basic Earning Power } \\
\text { Ratio }\end{array}$ & 0.055 & 0.104 & 0.123 \\
\hline
\end{tabular}

This ratio indicates the ability of SPUP's asset to generate operating income. As a rule of thumb, the higher the ratio, the better (Tugas, 2012). The ratios reveal that SPU has low profitability during the periods covered in the study.

Table 30. Return on total asset

\begin{tabular}{|l|l|l|l|}
\hline & 2016 & 2017 & 2018 \\
\hline $\begin{array}{l}\text { Return on total } \\
\text { assets }\end{array}$ & 0.051 & 0.096 & 0.123 \\
\hline
\end{tabular}

The above table presents how the assets of SPUP were being utilized. As a rule of thumb a higher return on asset is preferred since higher ROA means more return. The ratio on this table shows that SPUP increased its ROA from 2016 to 2018 which means that SPUP is improving.

\section{Strengths, Weaknesses, Opportunities and Threats of SPUP in the Balanced Scorecard}

\section{Strengths}

\section{Internal Process}

The following are the strong points of the University. SPUP demonstrated an effective and efficient basic processes as manifested by the provision of the best technology that ensure the effectiveness of its information to all its clients. The 
University promoted employee empowerment through the provision of training for employees' total development. Furthermore, the University has a well-defined system of collegial governance including written policies on governance and management. It also implemented a culture of quality and accountability into processes for regular internal/external audit and assessment; the academic policies of SPUP are consistent with the mission, aims, and objectives of the University and is responsive to national policies and international developments in higher education. All these were possible because the members of the governing body and management were selected based on clear guidelines and procedures. Furthermore, the academic policies of SPUP are consistent with its mission, aims, and objectives.

\section{Learning and Growth Perspective}

On the learning and growth perspective of the balanced scorecard, the University organized in-house training programs which were based from the training need assessment and training roadmaps of the employees. There were also training packages for new employees of the University. Furthermore, open opportunities for knowledge sharing was provided by the University where everyone has equal opportunity to share his/her knowledge and expertise.

\section{Customer Perspective}

On the customer perspective, the University maintained a clear information dissemination for students on implemented programs, activities and policies; students were exposed to real world of work through their practicum or field experience, the curriculum is relevant to the needs of the time. Furthermore, excellent management system and work competence of the dean/principal/guidance were demonstrated in the University all the time as manifested by prompt delivery of service to the customers. Finally, the customers were very satisfied with the provision of the waiting area in the University.

\section{Financial Perspective}

On the financial perspective, the University is solvent and has been financing most of its investments internally. In addition, there were more assets of the University that were financed by equity rather than debt, because the administrators are conservative in generating debt to support its operation. Furthermore, SPUP has an increasing total assets turnover in 2016 to 2018 which indicates efficient asset management since it was higher than the standard of 0.30 times (Tugas, 2012). Finally, SPUP has an increasing total assets turnover. 


\section{Weaknesses}

The weaknesses in the balanced scorecard will allow the University to realize the areas for improvements in which if not taken into consideration may result to problems and threats.

\section{Internal Processes}

The participants perceived that the University has some policies that at some points complicate the processes and research, creative work and innovation are copyrighted or patented.

\section{Learning and Growth perspective}

Few full time faculty have copyrighted/patented their creative works.

The national and international journal publications was limited.

Some faculty have not submitted their researches to either national or international publications.

Mentorship is not always observed in the University as assessed by the participants.

\section{Customer Perspective:}

On the customer perspective, the item on "faculty oftentimes shows concern and care for their students" has the lowest mean of 3.43, student's evaluation were done regularly also has the lowest mean of 3.79 , faculty usually starts and ends the class on time has a weighted mean of 3.51. The institutional service like physical facilities, maintenance services, security marshalls, comfort rooms, parking area are sometimes meeting the demands of the customers.

The items "Sometimes books and references are not up-to-date; the equipment in the Science laboratory and other laboratory services were not up-to-date and some equipment are not functional" were assessed by the participants as oftentimes.

The participants perceived that the cost of education in SPUP is oftentimes fair.

The items "books and references are not up-to-date; the equipment in the Science laboratory and other Laboratory services were not up-to-date; and some equipment are not functional" were perceived by the participants as oftentimes. 


\section{Financial Perspective}

On the financial perspective, the University had challenges in coping with the need to pay its current liabilities. In addition, the number of days of collection is beyond the 40 days which lead SPUP to having problem in liquidity as cash collection cannot be met on time for payment of current liabilities.

The liquidity ratio and short-term solvency is below the standard.

The University's fixed asset turnover was below the standard of 0.30 times. (Tugas, 2012)

\section{Opportunities}

From the four perspectives of the balanced scorecard, the University has the opportunity of offering attractive reward for those employees who have copyrighted/patented their creative works, and also for those with national and international journal publications. Moreover, promoting mentorship can be taken into consideration.

\section{Threats}

The University may possibly be facing the following threats like having high receivables due to slow collection period, another threat of having fixed assets not fully utilized/maximized.

\section{CONCLUSION}

Based on the aforementioned findings, the researcher concludes that the scorecard of SPUP has positive performance in the internal processes, learning and growth, and customers' perspectives. It adopted aggressive working capital management in its financial perspective of the balanced scorecard brought by low liquidity and short-term solvency. It has less performance in the financial perspective of the Balanced Scorecard. 


\section{RECOMMENDATIONS}

In the light of the findings and conclusions drawn, the following recommendations are deemed important:

1. SPUP Management may consider employing more rigorous collection policies of the receivables.

2. The administration may consider giving attractive compensation package to encourage faculty loyalty, dedication and commitment to their teaching ministry in the University.

3. A similar study may be conducted to include a tracer study from the SASTE, SNASH, and SITE graduates as secondary data to validate the result of this study.

4. The administration may consider offering international exposure to employees to enhance their skills in teaching.

5. SPUP may review the proposed strategies in this study for its consideration.

6. SPUP can intensify the financial perspective of its operations to achieve a balance in the scorecard. 


\section{References:}

Published Studies:

Kaplan RS and Norton DP, "The Balanced Scorecard - Measures that drive performance", Harvard Business Review, 1992 Jan/Feb, pp71-79.

Karathones Demetrius and Karathones Patricia (2005), Applying the balanced scorecard to education.

Manville,(2006). The implementation of a performance management system using balanced scorecard in a non-profit and medium sized enterprise (SME)

McDevitt, Giapponi, and Solomon (2008). Strategy revitalization in academe: a balanced scorecard approach. https://doi.org/10.1108/09513540810844549

Norrie and Walker (2004. A Balanced Scorecard Approach to Project Management Leadership. https://doi.org/10.1177/875697280403500406

Othman, R. (2008). Enhancing the effectiveness of the balanced scorecard with scenario planning. International Journal of Productivity and Performance Management, 57(3), 259-266. doi:http://dx.doi.org/10.1108/17410400810857266

Palmer, P and O'Neil (2004) Importance of performance analysis: a useful tool for directing contnuous quality improvement in higher education. https://doi.org/10.1108/09684880410517423

Tugas, Florence,(2012). Comparative analysis of the financial ratios of listed firms belonging to the education subsector in the Philippines.

Urrutia and Eriksen, (2005). Applications of the balanced scorecard for strategic management and performance measurement in the health sector

\section{Journal:}

Baker, J., Jones, D. R., Cao, Q., \& Song, J. (2011). Conceptualizing the dynamic strategic alignment competency. Journal of the Association for Information Systems, 12(4), 299-322. Retrieved from http://search.proquest.com/docview/866306531?accountid=33657. https://doi.org/10.17705/1jais.00265 
Bryant, L., Jones, D. A., \& Widener, S. K. (2004). Managing value creation within the firm: An examination of multiple performance measures. Journal of Accounting Research, 16, 107-131. Center for International Private Enterprises (2011). Philippines property markets scorecard: Conditions for small businesses. Retrieved Jan. 6, 2014, from www.cipe.org/publications/detail/philippinesproperty-markets-scorecard. https://doi.org/10.2308/jmar.2004.16.1.107

CHED Memorandum Order (CMO) No. 46, series 2012, Policy-standard to enhance quality assurance (QA) in Philippine higher education through an outcomes based and typology-based QA.

Kalender, Zeynep, et al (2016) The fifth pillar of the balanced scorecard: sustainability. $12^{\text {th }}$ International Strategic Management Conference, ISMC 2016, 28-30, Antalya, Turkey. Marmara University, Istanbul Goztepe Campus, 34722, Turkey

Kosta, Katerina (2019), Institutional Sustainability Assessment, Oxford Brookes University, Oxford UK. Springer Nature Switzerland AG 2019. W. Leal Filho (ed). Encyclopedia of Sustainability in Higher Education, https://doi.org/10.1007/978-3319-63951-2_196-1. 